\title{
Approaching the Use of Facebook to Improve Academic Writing and to Acquire Social Competences in English in Higher Education
}

\author{
María Martínez Lirola \\ University of Alicante, Spain \\ University of South Africa (UNISA), South Africa \\ ORCID: 0000-0002-6427-425X
}

Received: 20 May 2021

Accepted: 26 Sep 2021

\begin{abstract}
This article offers a proposal for integrating the social network Facebook into an English as a Foreign Language (EFL) classroom in tertiary education. The main objectives of this article are the following: 1 . To offer a pedagogical proposal so that students can develop written skills and grammar at the same time that they acquire social competences using Facebook and 2. To know students' opinions about the use of Facebook and the main social competences that they have acquired while using this social network in the teaching-learning process. The methodology is mainly qualitative-descriptive although some quantitative data is offered with the results of a questionnaire students completed. The data were collected through students' posts in the Facebook discussions and a questionnaire.

The findings reveal the main grammar mistakes observed in students in the Facebook discussions and how Facebook is an appropriate social network for the participation of students in cooperative discussions on social topics and for the acquisition of social competences such as cooperation or communication. The results of the questionnaire show that students have a positive opinion about practicing the written skill in Facebook and they are aware that, apart from learning English, they also acquire social competences.
\end{abstract}

Keywords: English language online teaching, social networks, Facebook group, writing skill, social competences

\section{INTRODUCTION}

The twenty-first century is a virtual era that involves rethinking the role of education and the incorporation of digital skills apart from the content requested in any subject (Cózar-Gutiérrez \& Sáez-López, 2016). In this sense, Information and Communication Technology (ICT) and Social Networking Sites (SNS) can play a key role in updating education, because their use can have pedagogical purposes (Lin et al., 2016; Rwodzi et al., 2020).

This article offers a proposal for integrating the social network Facebook into an English as a Foreign Language (EFL) classroom in tertiary education. The purpose of this study is to show how Facebook provides opportunities to develop writing in English and to acquire social competences in the EFL classroom. In fact, this research establishes a relationship between using Facebook to motivate students to write and to reflect on global social topics associated with the oral presentations they have to prepare every week. In this sense, writing is combined with other skills and with the revision of grammar at the same time that both contribute to promoting the acquisition of social competences. Students have to reflect upon the social issues that the oral presentations were based upon. 
The main objectives of this article are the following: 1 . To offer a pedagogical proposal so that students can develop written skills and grammar at the same time that they acquire social competences using the social network Facebook and 2. To know students' opinions about the use of Facebook in an EFL subject and the main competences that they have acquired while using this social network in the teaching-learning process.

The hypothesis is that Facebook is an appropriate social medium to integrate the practice of different skills and grammatical aspects at the same time that social competences are acquired in an educational context. Consequently, the paper will be guided by the following research question: Is Facebook a suitable social network for students to develop written skills and to revise grammar at the same time that they acquire social competences?

This study is justified because, during the pandemic, students' attendance in class was restricted. This also meant there were limited opportunities to interact and discuss different points of view or to work on cooperative writing in the classroom. For this reason, the teacher chose Facebook so that students had a social network as a supplementary platform of the subject where they could write during the semester and as a collaborative learning tool. The popularity of social media among young learners provides opportunites for students to communicate using English for academic purposes. In this sense, students can write their own posts, and they can read what others write, which facilitates interaction in a virtual environment.

The fact that the teaching-learning process was dual, i.e., teaching was synchronously done with students in the classroom and students connected online (the students in the classroom were different each week because they were rotating) was a challenge that involved difficulties. Students at home had to be able to hear the comments that students made in the classroom. Consequently, Facebook offered the opportunity to post comments any time for both students in the classroom and students at home. In this way, students' posts could be read any time by the other students, and students could write before, during or after the lecture. What was initially an oral practice activity also became a written activity that involved the use of the grammar and vocabulary studied in the subject.

\section{LITERATURE REVIEW}

This section is divided in two sub-sections: the first is more general and concentrates on the use of technology for educational purposes; the second is more specific and deals with the educational uses of Facebook.

\section{Technology for Educational Purposes}

In the last few decades, technology has had a key role in education because it has been used to facilitate students' learning. It has an integral part in the preparation of the lessons and in the teaching-learning process (Ahmadi, 2018; Pourhossein, 2017). The use of the internet increases students' motivation (Arifah, 2014). Following Ahmadi (2018, p. 118): "When learners learn with technology, it assists them in developing their higher order thinking skills. It can be concluded that the true combination of multimedia and teaching methodology is very important to attract learners' attention towards English language learning."

The way students learn through technology is diverse, for example, mobile learning (m-learning) and MobileAssisted Language Learning (MALL) (Çakmak, 2019a; Kukulska-Hulme \& Viberg, 2018), wikis and blogs (Seaman \& Tinti-Kane, 2013). Social networking platforms such as Facebook, Twitter, WhatsApp or Instagram have been applied to foreign language education for more than a decade (Alnujaidi, 2017; Andujar \& Salaberri-Ramiro, 2019; Çakmak, 2019b; Gallardo-López \& López-Noguero, 2020; Gettman \& Cortijo, 2015; Lomicka \& Lord, 2016; Vahdat et al., 2020). Their use is justified because they can facilitate language learning at the same time that digital competence is incorporated in the teaching-learning process (Alsaied, 2017; Martín-Monje et al., 2018; Solmaz, 2018).

Social media facilitate interaction and continuous learning. They also promote online communication (Ruiz \& Fachinetti, 2018) by creating a network where students generate content and share knowledge at the same time that they interact with each other, by promoting participation and cooperation (Cela-Ranilla et al., 2017; Fernández-Ferrer \& Cano, 2019). This involves blended learning models (Chen Hsieh et al., 2017; Hung, 2015; 
Law et al., 2019), which facilitates education taking place in more autonomous contexts than traditional classrooms.

\section{Facebook for Educational Purposes}

This article will concentrate on the use of Facebook in the English as an EFL classroom within the context of a Spanish university. Facebook is one of many Web 2.0 tools (wikis, YouTube, podcasts, etc.) that are listed as having potential applications for teaching and learning. It is used to maintain or create new networks, which justifies it being an educational micro-community of students registered in a language subject in tertiary education (see Methodology).

The literature on the educational uses of Facebook is constantly growing. This section offers an overview of the direction that research has taken on the pedagogical uses of Facebook. Then it concentrates on the literature review on using Facebook for English learning.

Facebook was created in February 2004 by Mark Zuckerberg at Harvard University. Membership was originally limited to Ivy League college students but was later (since 11 September 2006) extended to anyone with a valid email address (Torgeson, 2006). According to the report Digital 2020: Global Digital Overview, prepared by the companies 'We are social' and 'Hootsuite' (2020), about 3.484 billion people use social networks, that is, $45 \%$ of the world's population. The number of people who use social networks in an active way in Spain is 29 million. In January 2020, Facebook was the third most visited website in the world, only surpassed by Google and YouTube, and had a total of 2.41 billion active monthly users (Newberry, 2020). In December 2020, Martín del Campo Fernández-Paniagua (2020) affirmed that Facebook can be considered the most famous social network in the world, used by $87 \%$ of users, followed by YouTube (68\%) and Instagram (54\%).

Some researchers have concentrated on using Facebook for teaching and learning in an innovative way and how this has an effect on effective learning (Daher, 2014; David \& Akcaoglu, 2014; Li et al., 2013; Shraim, 2014). There are also studies that have explored the effect of using Facebook on students' interests and motivation (Aubry, 2013; Ru-Chu, 2011) and on the relationship between students and teachers (Ellison et al., 2011; Mazer et al., 2007). In addition, research has explored the positive and negative effects of Facebook (Hutchens \& Hayes, 2014; Manca, \& Ranieri, 2016; Vural, 2015). Some of the main positive aspects are its benefits for interaction and collaboration and the possibilities it offers to share interests and to make connections; students can develop content and language knowledge through Facebook; it favors positive relationships between students and between students and teachers; it can also contribute to incidental learning of language skills (Adi Kasuma, 2017). Some of the negative aspects are that learners can be distracted by the different features of Facebook such as friend requests, notifications, and chat box. There are also issues of security and privacy that can be problematic. Moreover, it involves extra work for teachers because they have to monitor the suitability of the language so that students do not learn inaccurate language production in online environments, for example (Marín-Díaz \& Cabero-Almenara, 2019; Miller, 2020).

Focusing on English learning, generally, studies concentrate on the use of Facebook to improve students' English communication skills (Adi Kasuma, 2017; Chugh \& Ruhi, 2018; Dweikat, 2016; Mariappan et al., 2017), paying special attention to post classroom materials, to reach students with learning materials, to post words and definitions for vocabulary review, to share questions and ideas about discussions, etc. (Kabilan et al., 2010).

Research has explored specifically the use of Facebook to improve writing in English (Annamalai, 2016; Ibrahim, 2013; Majid et al., 2015; Shih, 2011). For example, Melor and Salehi (2012) highlight the effectiveness of Facebook to improve writing at the same time that students can learn new vocabulary from reading other students' comments. Similarly, Vikneswaran and Krish (2014) point out that students wrote better in English through Facebook thanks to peer influence, due to the fact that students exchanged ideas with each other. However, hardly any study concentrates on adding a reflection on social topics to writing and on the acquisition of social competences. The few studies found show that the acquisition of social 
competences contributes to students' engagement and socialization (Ainin et al., 2015; Junco, 2012). In consequence, this study will focus on that area in order to show that the implementation of the writing proposal through Facebook goes beyond the development of writing skills, by incorporating social competences in the study.

\section{METHODOLOGY}

\section{Design of the Study}

The methodology is mainly qualitative-descriptive because it is based on the compilation and analysis of the students' posts in the discussions in Facebook. The teacher divided students into 18 groups ( 9 in group A and 9 in group B) so that they could prepare a cooperative oral presentation on a social topic of their choice. Each presentation had to be followed by a discussion in Facebook. Table 1 shows the social topics discussed during the semester. The discussions were organised by the teacher during the first three weeks. The topics were violence in schools, human rights, and stereotypes.

Table 1. Social topics discussed in groups

\begin{tabular}{ll}
\hline Topics: Group A & Topics: Group B \\
\hline Activism & Recycling \\
Plastic surgery & The impact of music in society \\
Drag as a cultural phenomenon & Mental disorders \\
Situation and effects of drugs in society & Music and cultural identity in 20th-century U.S. \\
& (origins and influences) \\
Mental health & The effects of alcohol \\
Children and social media & Fake news \\
Education & Feminism \\
Stereotypes in advertising & Differences in eating habits \\
Women, the hidden face of history & Racism \\
\hline
\end{tabular}

Facebook was a complementary tool to the UACloud platform provided by the University of Alicante, which was used by the teacher to provide materials for students, to answer tutorials, to hand in tasks, etc. The Facebook group was created at the beginning of the semester, and all the students registered in the subject were invited to join the page. Students' comments on Facebook were taken into account for the grade in attendance and participation. In this way, the active participation of students in an online discussion was encouraged. The group in charge of the week's discussion had to post a list of at least five questions. Students were asked to use that advanced vocabulary and the formal grammatical expressions explained in the classroom on the posts. The results of the questionnaire students answered the end of the semester and the analysis of the main gramatical errors of the students offer some quantitative data based on students' answers and posts.

\section{Participants and Context}

The participants were 94 third-year students enrolled in the subject English Language V (79 women and 15 men) during the first semester of the 2020-2021 academic year of the degree in English Studies at the University of Alicante. Most students were 20 years old and had studied English from the first year in the degree. They would like to work as high school teachers or in international companies when they finish the degree.

The main aim of the subject is that students develop the different skills in English in order to acquire level C1 (Council of Europe, 2001). The subject was taught twice a week for two hours each day during fifteen weeks. The first two hours were devoted to academic writing and to grammar; the second two hours were devoted to oral and interaction skills through oral presentations and discussions. 


\section{Research Instruments}

The research instruments were students' posts in the Facebook group and a questionnaire constructed by the teacher. The Facebook group 'English Language V' allows students to interact based on a common interest or affilitation, i.e., students participate in this study because they are registered in the subject. The teacher collected all the posts and revised the grammar and vocabulary. After that, a classification of the main grammatical mistakes was established so that students could get some feedback for the next grammar lesson.

The questionnaire on google forms consisted on ten questions whose purpose was to know the opinion of the students who have participated in the Facebook discussions during the semester (see Appendix 1). There were three yes/no questions and seven using the Likert scale $(5=$ strongly agree, $4=$ agree, $3=$ neutral, $2=$ disagree, $1=$ strongly disagree).

\section{Procedure}

The teacher decided to create a Facebook group because the COVID-19 pandemic involved uncertainty in the teaching-learning process in the number of students who could come to class and of the types of activity that could be done in the classroom. Moreover, the possibility that, in any moment, a resurgence of the pandemic would limit students' access to the classroom was another reason to choose Facebook. The limitation of students per classroom and the distance that it was necessary to keep among them made the teacher think of the necessity of choosing a social network that facilitated cooperation between students without being physically present and of the necessity of providing a virtual enviroment to facilitate the acquisition of skills and competences of the subject with only some students present in the classroom.

Firstly, the teacher created the Facebook group 'English Language $V$ ' and informed students about it so that they could join this page and create a Facebook account if they did not have one. Secondly, the teacher posted discussion topics on social issues during the first three weeks of the semester so that student could share their opinions, read other students' comments, practice vocabulary associated with the topic being discussed and reflect on the social issue studied every week. Students were informed that the Facebook group was only used for the discussions associated with the oral presentations. If they had questions about the subject, they had to use the platform UACloud provided by the University of Alicante.

From week four on, one group of students was in charge of posting the discussion topic and the questions based on the topic of the oral presentation in Facebook. The discussions in the Facebook environment were confined during the lessons and outside classroom time. In fact, each group was asked to post the questions for the discussion at least two days before the oral presentation. Thirdly, the teacher revised students' posts and prepared a list with the main grammatical mistakes found in the posts. Next, the teacher revised the grammatical mistakes in the next grammar class and asked students to revise the grammar associated with them. The discussion contents with grammatical mistakes were reported by using quotes from the students' posts without indicating students' names. Finally, if students had doubts or questions, they could ask the teacher in a tutorial. These phases continued until the last week of the semester, when students presented the last oral presentation and the discussion through Facebook.

\section{ANALYSIS}

This section is divided in two sub-sections: the first offers an overview of the main errors that the teacher observed in the students' posts in Facebook; the second one concentrates on the results of the questionnaire that students completed at the end of the teaching-learning process.

\section{Students' Errors}

The total number of discussions in Facebook organised by students was eighteen (nine per group), which corresponds with the eighteen oral presentations that took place every week (see Table 1). The teacher revised students' posts in order to observe the main grammatical mistakes so that they could be corrected 
in the weekly grammar classes. Among the students, $39 \%$ had no mistakes, $47 \%$ had between one and three mistakes and $14 \%$ had more than three mistakes at the beginning of the semester. After the grammar classes each week, students improved their grammar: $66 \%$ students had no mistakes, $24 \%$ had between one and three mistakes and $10 \%$ had more than three mistakes at the end of the semester, as we can see in Figure 1.

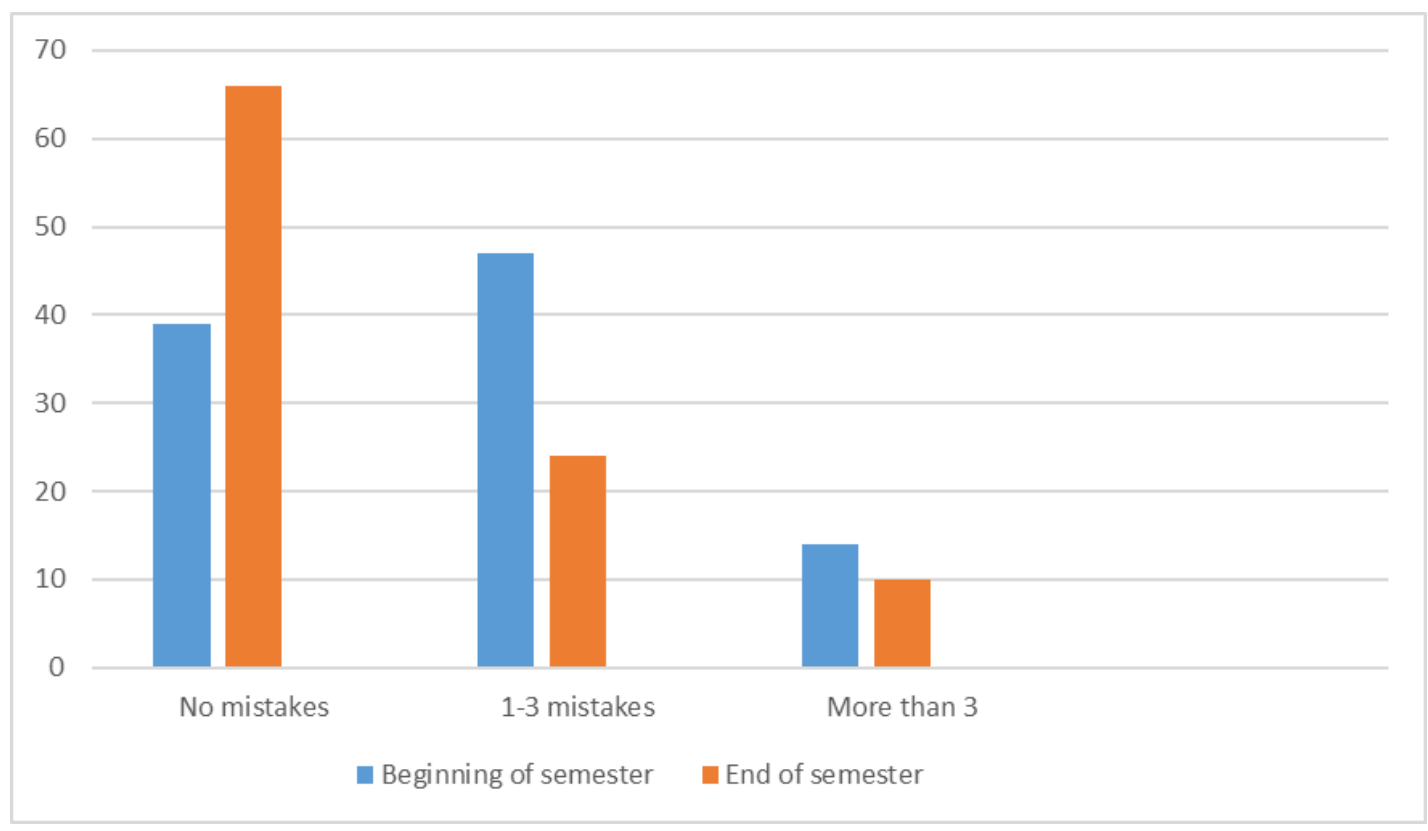

Figure 1. Comparison of students' mistakes at the beginning and the end of the semester

There were other types of mistake (13\%) such as problems with modal verbs ('All the schools must to have psychologists'), third person singular ('I think that this type of education have to start from home and school'; Sometimes, this addiction even affect the children's character, as they are more irritable and anxious), or subject missing as a result of using literal translation from Spanish ('As was explained in the last paragraphs, accentism is a threat. Is dangerous for people to feel like an intruder, humiliated of their origins and vulnerable in a society that refuses to accept that accents are not something to be judged for'). At the end of the semester, the teacher observed the same types of mistake in the students who still made mistakes: articles were the most problematic grammatical point (34\%), followed by subject-verb agreement (26\%), word order (22\%), faulty reference (12\%) and other mistakes (6\%), as we can see in Figure 2.

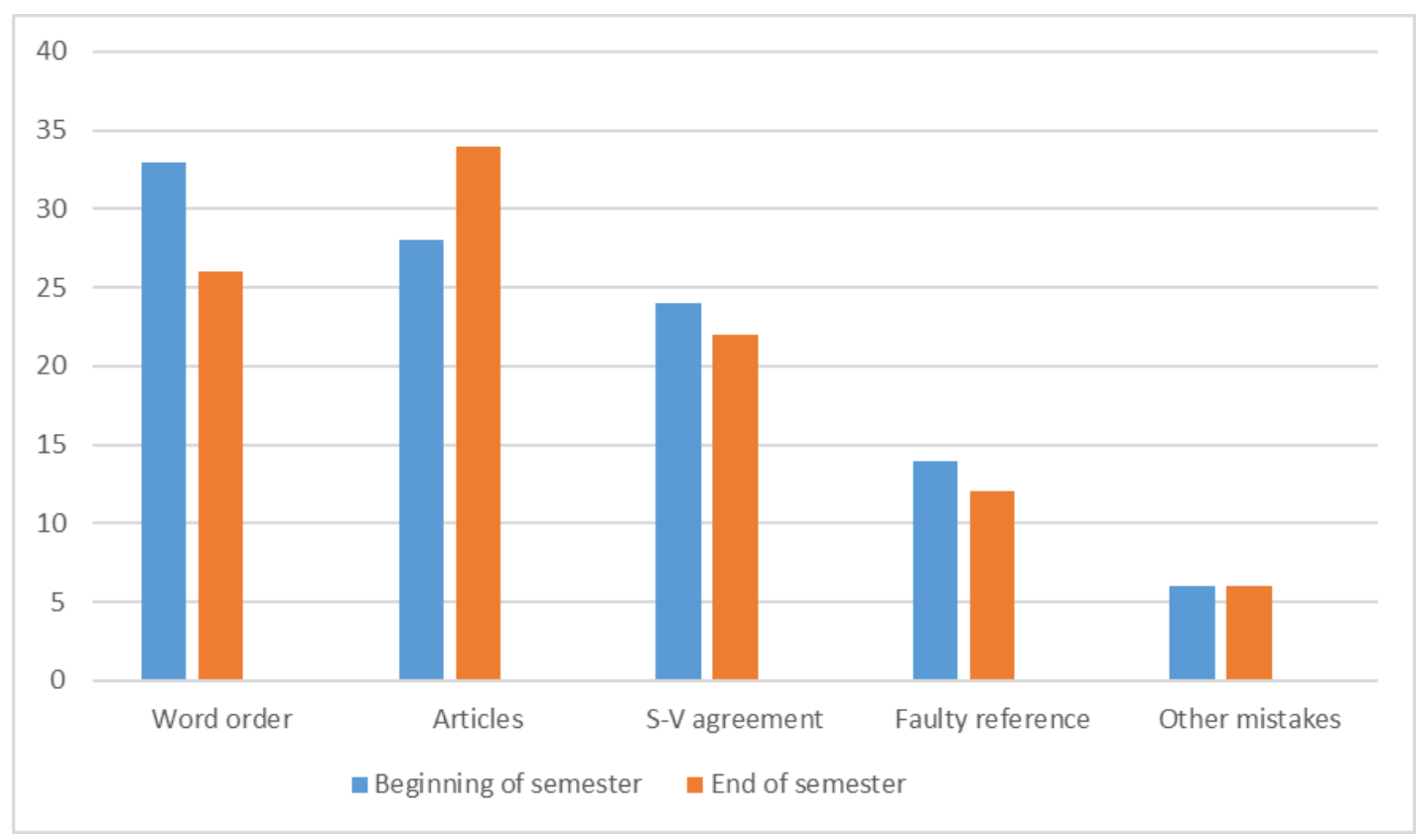

Figure 2. Types of mistakes at the beginning and at the end of the semester 
The main problems in the comments in Facebook are connected with word order and syntax, because students tend to write following the syntactic order in their first language. In this sense, firstly, it is essential that students know that English is an SVOA language. Secondly, they have to be aware of structures such as cleft sentences and existential sentences, in which the order SVOA has certain modifications.

Issues in word order are also associated with literal translation from Spanish, as we can see in these examples: 'The latest news is that is constantly increasing the number of overweight people which is motivated by inadequate and unhealthy diets' and 'I am the kind of person that prefers to be at home and now that I have been taking away the option of being at uni with my friends makes me isolate more'. These students will also need to shorten the sentence, revise prepositions, and improve word order in general. The following example shows that the student is also translating from Spanish: 'In this paragraph, - there will be explained what cosmetic surgery actually is'.

One of the main difficulties related to word order has to do with the position of adverbials. In the following example, the prepositional phrase 'in the child' appears before the verb, breaking the unmarked order of sentences in English SVOA: 'This lack of attention of the father towards his son or daughter in the child can generate a feeling of abandonment'. In a similar way, students have problems with inversion as the following example points out: 'But not only I was angry by the things I saw in advertising but also by the comments that people made they offer you all they have'.

There were many problems with the use of articles, because students did not distinguish when they needed to use them. For this reason, examples such as the following are frequent: 'The life can be hard' or 'The critical thinking is essential'. In these examples students forget that abstract uncountable nouns normally take the zero article when referring generally to an idea. However, they also have trouble using the definite article with abstract uncountable nouns when talking about a specific example, as in happens in: 'Knowledge which people get in advertising make them be in favor of plastic surgery'. Students do not use the definite article in this sentence in which they are talking about specific knowledge, i.e., that people get from advertising. I also found this mistake in which the student uses ' $a$ ' instead of 'an': 'Sexuality is a human biological function such as others (such as others is incorrect; it should be like other functions). We live in a open society, and social issues as sex, suicide, drugs, LGBTQ+ need to discussed'.

Students also have difficulties with subject-verb agreement. It is quite common to find a plural subject with a verb in singular or vice versa, i.e., a singular subject with a verb in plural, as we can see in the following two examples: 'Everyone has the right to live the way they want', 'I strongly believe that lot of people is not aware of their addiction to tobacco and alcohol', or 'In addition, there are some other people who doesn't identify themselves neither as a woman nor as a man, these are called "agender"' (this student also has a problem with using the negative). The fact that some students have problems with subject-verb agreement makes us think of the reasons for this. For example, using 'people' with a singular verb instead of plural, which is a very common mistake, is understood because the word 'people' is followed by a singular verb in Spanish.

Some difficulties were observed with faulty reference and pronominalization in examples in which there is no agreement between the pronoun and the word it refers to, or it is not clear what the reference of the pronoun is: 'Everyone has the right to live the way they want' or 'Many of the people affected explained his feelings in public'. In these cases, it is necessary for students to remember that pronouns must agree in number with their antecedents, or that the antecedent of a pronoun must be clearly understood.

After analysing students' errors, I used drilling exercises in the classroom from the grammar book Advanced Grammar in Use (Hewings, 2013) so that students could work on the grammatical points that needed further reinforcement. This practice was at sentence level; then, students were expected to apply this knowledge to the essay that they had to write at the end of the semester and to the Facebook discussions. Most of the students who attended class did not have problems with the grammatical aspects I have refered to (84\%). After this, I selected several paragraphs from their essays and from the Facebook discussions so that they could mark the few mistakes that there were and pay attention to the correct use of the grammatical points that were emphasized during the semester. 


\section{Results of the Questionnaire}

In question number 1 , it is surprising that most of the students registered in the subject $(92,7 \%)$ say that they had not used Facebook for educational purposes in any other subject, whereas $7,3 \%$ had used it. Moreover, it is noteworthy that, when students were asked if they were more aware of social situations after participating in the preparation of the oral presentation and discussion based on a social topic (question 2), $97,3 \%$ offered a positive answer. The main reasons for this answer are the following: a) the discussions made them go deeper into the topic and be more aware of the social situation being discussed; $b$ ) reading other students' comments made them more critical of the social topic being discussed and taught them something new and, c) the information found on the topic offered them different points of view on the social issue under analysis.

When students were asked about the main social competences they had developed with the preparation and participation in oral presentations and the discussions through Facebook (question 3), some marked all the competences; $79.3 \%$ marked cooperation, followed by communication (78\%). The other competences were chosen by a lower percentage of students: leadership (25.6\%) and conflict solving (36.6\%). The answers to questions 7 to 10 are presented in Table 2, so that it is easier to see the percentage obtained using the Likert scale.

Table 2. Students' answers to questions 4-7

\begin{tabular}{|c|c|c|c|c|c|}
\hline \multirow{2}{*}{ Questions } & \multicolumn{5}{|c|}{ Likert scale } \\
\hline & 1 & 2 & 3 & 4 & 5 \\
\hline $\begin{array}{l}\text { 4. Has the use of the Facebook group contributed positively to } \\
\text { improving your language knowledge? }\end{array}$ & $6.1 \%$ & $15.9 \%$ & $34.1 \%$ & $20.7 \%$ & $23.2 \%$ \\
\hline $\begin{array}{l}\text { 5. Has the use of the Facebook group contributed positively to } \\
\text { improving your motivation to communicate using English? }\end{array}$ & $7.3 \%$ & $19.5 \%$ & $31.7 \%$ & $19.5 \%$ & $22 \%$ \\
\hline $\begin{array}{l}\text { 6. Has the use of the Facebook group contributed positively to } \\
\text { improving your knowledge about social topics? }\end{array}$ & $18.3 \%$ & $15.9 \%$ & $26.8 \%$ & $22 \%$ & $17.1 \%$ \\
\hline $\begin{array}{l}\text { 7. Has the participation in the Facebook group contributed to improving } \\
\text { your writing fluency? }\end{array}$ & $9.8 \%$ & $15.9 \%$ & $32.9 \%$ & $17.1 \%$ & $24.4 \%$ \\
\hline $\begin{array}{l}\text { 8. Could Facebook be considered as an effective supplementary } \\
\text { learning platform to practice writing in English? }\end{array}$ & $12.2 \%$ & $18.3 \%$ & $35.4 \%$ & $18.3 \%$ & $18.3 \%$ \\
\hline $\begin{array}{l}\text { 9. Could Facebook be considered as an effective supplementary } \\
\text { learning platform to read in English? }\end{array}$ & $15.9 \%$ & $17.1 \%$ & $30.5 \%$ & $18.3 \%$ & $18.3 \%$ \\
\hline $\begin{array}{l}\text { 10. Could Facebook be considered as an effective supplementary } \\
\text { learning platform to overcome language mistakes? }\end{array}$ & $9.8 \%$ & $15.9 \%$ & $36.6 \%$ & $22 \%$ & $15.9 \%$ \\
\hline
\end{tabular}

When students were asked if the Facebook discussions had contributed positively to improving different aspects such as their language knowledge, their motivation to communicate using English, their knowledge about social topics or to practicing writing, reading and to overcoming language mistakes (see Table 2), almost half chose the highest numbers on the scale ( 4 and 5), around one-third selected 3 , and around onefourth of the students surveyed chose the lowest numbers on the scale (1 and 2).

The variety of responses reflects students' personalities and learning styles, which is always an enriching factor in the language classroom. It is interesting that about the same number of students chose number 3 on the scale to point out that Facebook is an effective supplementary learning platform to practice writing (35.4\%) and to read in English (30.5\%), which shows the relationship between the skills. In this sense, it is observed that writing posts in Facebook is also associated with reading the posts that other students write to agree, disagree or to make reference to any aspect in the discussions. In addition, these two skills are associated with speaking and listening, because the Facebook discussions always take place after students have participated in a cooperative oral presentation.

Finally, the fact that almost $40 \%$ of the students chose numbers 4 and 5 on the scale to evaluate Facebook as an effective supplementary learning platform to overcome language mistakes shows that students are aware of the methodology used by the teacher and of the effectiveness of using the posts in Facebook to revise grammar in the classroom. 


\section{DISCUSSION}

Facebook is a social network that facilitates interaction and engagement in communication in the teachinglearning process. The Facebook group 'English Language $\mathrm{V}$ ' is an instrument that allows students to interact based on the common fact that they are registered in the subject at the same time that they engage with the social topic that is discussed every week. Integrating Facebook into a language subject as a supplementary learning tool can provide students with a real and natural setting of communication and enhance their motivation. Consequently, students learn easily and actively by interacting with their classmates and teacher using social network that they also use for personal communication.

Encouraging students to communicate through Facebook discussions in and outside the classroom offers students many opportunities to write in English without time restrictions. Moreover, students learn and write at their own pace, which promotes a learner-center approach. Consequently, shy students can be more confident about writing and interacting than when the interaction takes place face to face in the classroom. Facebook is a flexible environment that students can access synchronously and asynchronously (Shih, 2011).

The flexibility already mentioned has implications for teachers and educator managers because it is necessary that they check students' comments in Facebook regularly so that they can provide students with the appropriate feedback and address the main mistakes as soon as they appear. In this sense, it is useful that teachers advice students about the main times of the day and of the week they will check the Facebook group so that students do not expect an immediate answer to their comments or some suggestions to improve their writing. In addition, using Facebook as a pedagogical resource is challenging for teachers because they have to learn about the multiple uses of Facebook in general in order to adapt it for the educational activity selected.

Moreover, the use of Facebook is also challenging for students because they have to clearly distinguish the academic use of Facebook from the personal or entertainment one. This challenge is associated with the use of standard English for the online discussions, i.e., the teacher needs to make sure that students avoid informal English or Spanglish so that the quality of English in online discussions is as good as possible. In this sense, it is essential that the teacher insist on the importance of revising the writing before it is posted in Facebook, which involves revising vocabulary, grammar and spelling.

The Facebook group 'English Language V' encouraged group cohesion and the collective creation of knowledge because students got engaged with the topic that was discussed each week by answering the questions that the presenting group had prepared, by making reference to what other students had said in the Facebook posts and by establishing connections between the various discussions. Consequently, collaborative learning and a participatory methodology are observed in the teaching-learning process.

Although the teacher encouraged students to write in Facebook during the teaching-learning process, some students were reluctant to do so, which means that they did not make the most of the opportunity of using Facebook to practice writing skills. On balance, Facebook contributed to promoting reading (some students did not write, but they read what other students wrote) and cooperative learning, because students can learn from each other by reading the different posts.

The fact that the oral presentations are cooperative and that the same group has to prepare and post the questions for the discussion in Facebook and comment on other students' posts also reinforces collaboration between group members. Consequently, communication and cooperation are social competences that are promoted by participating in the Facebook discussions. The group in charge of organising the Facebook discussion each week had to motivate the rest of the classmates to participate. This contributed to promoting leadership, a social competence that students need for the labout market.

The results of the questionnaire show that Facebook is effective for English learning, for connecting different skills and for improving students' literacy. The social topics that frame students' interaction through Facebook contribute to students' development of language knowledge and social competences at the same time. It is remarkable that some groups (10 out of 18 ) not only shared some questions to discuss aspects 
about the oral presentation topic, but they also shared the links to some videos and articles associated with the topic. This shows that students took the innitiative to provide extra information for their classmates.

Measuring the academic performance of students though Facebook is always challenging: it is difficult to select the aspects to be analysed and to determine the type of feedback that students will receive. In this study, giving students the opportunity to discuss social topics had a central role although the quality of the language was also important and the grammar mistakes were also analysed (see Figure 2).

\section{CONCLUSIONS}

Technology and social networks such as Facebook facilitate effective distance learning in a context like the one we live in nowadays, where a pandemic has challenged traditional classroom practices. This article has explored the use of Facebook for online discussions in higher education and has observed that Facebook discussions contribute to forging interaction and good relationships between students and to facilitating the acquisition of social competences.

Using Facebook in an English subject offers the opportunity to apply a social network environment so that students can learn about social topics at the same time that they practice their English. In this sense, Facebook promotes web-based interaction between students outside the classroom, i.e., there is flexibility to interact without having the time and space constraints of the classroom. This reinforces autonomous learning, because students were free to participate in the Facebook group synchronously and asynchronously during the teaching-learning process.

In addition, the teacher decided to use Facebook for online discussions as a substitute for cooperative writing in the classroom because it shows that the English language is constructed throught the cooperative-based discussions on social topics that take place every week. In fact, Facebook is an appropriate tool to stimulate students to write in English at the same time that they reflect on social topics. Consequently, different skills and competences are integrated and developed during the teaching-learning process.

The use of Facebook in the subject English Language $V$ involved incorporating into the classroom a new trend of today's communication and a change in students' academic performance. In this sense, students can associate using Facebook with their personal communication, which means that the task of academic writing done through Facebook can be more motivating than doing it in the classroom without using social network. In conclusion, Facebook contributes to improving students' writing in English language and promotes authentic language interaction and the acquisition of social competences.

Funding: Author received no financial support for the research and/or authorship of this article.

Declaration of interest: Author declares no competing interest.

Data availability: Data generated or analysed during this study are available from the author on request.

\section{REFERENCES}

Adi Kasuma, S. A. (2017). Four characteristics of facebook activities for English language learning: A study of Malaysian university students' needs and preferences. Advances in Language and Literary Studies, 8(3), 155-171. https://doi.org/10.7575/aiac.alls.v.8n.3p.155

Ahmadi, M. R. (2018). The use of technology in English Language Learning: A literature review. International Journal of Research in English Education, 3(2), 115-125. http://ijreeonline.com/article-1-120-en.pdf

Ainin, S., Naqshbandi, M. M., Moghavvemi, S., \& Jaafar, N. I. (2015). Facebook usage, socialization and $\begin{array}{llll}\text { academic } & \text { Computers \& }\end{array}$ https://doi.org/10.1016/j.compedu.2014.12.018

Alnujaidi, S. (2017). Social network sites effectiveness from EFL students' viewpoints. English Language Teaching, 10(1), 39-49. https://doi.org/10.5539/elt.v10n1p39 
Alsaied, H. I. K. (2017). Perceived effectiveness of social media as an English language learning tool. Arab World English Journal, 8(1), 79-93. https://doi.org/10.24093/awej/vol8no1.7

Andujar, A., \& Salaberri-Ramiro, M. S. (2019). Exploring chat-based communication in the EFL class: Computer and mobile environments. Computer Assisted Language Learning, 34(4), 434-461. https://doi.org/10.1080/09588221.2019.1614632

Annamalai, N. (2016). Exploring the writing approaches in the Facebook environment. Teaching English with Technology, 16(1), 71-87. http://www. https://files.eric.ed.gov/fulltext/EJ1135929.pdf

Arifah, A. (2014). Study on the use of technology in ELT classroom: Teachers' perspective (M.A. thesis), Department of English and Humanities, BRAC University, Dhaka, Bangladesh.

Aubry, J. (2013). Facebook - induced motivation shifts in a French online course. TechTrends, 57(6), 81-87. https://www.learntechlib.org/p/154285/

Çakmak, F. (2019a). Mobile learning and mobile assisted language learning in focus. Language and Technology, 1(1), 30-48. https://dergipark.org.tr/tr/download/article-file/665969

Cakmak, F. (2019b). Social networking and language learning: Use of Instagram (IG) for evaluating oral communication skill. In A. Andujar (Ed.), Recent tools for computer- and mobile-assisted foreign language learning (pp. 103-131). IGI Global.

Cela-Ranilla, J. M., Esteve-González, V., Esteve-Mon, F., González-Martínez, J., \& Gisbert-Cervera, M. (2017). El docente en la sociedad digital: Una propuesta basada en la pedagogía transformativa y en la tecnología avanzada [The teacher in the digital society: A proposal based on transformative pedagogy and advanced technology]. Profesorado, Revista de Curriculum y Formacion del Profesorado, 21(1), 403-422. https://recyt.fecyt.es/index.php/profesorado/article/view/58073

Chen Hsieh, J. S., Wu, W. C. V., \& Marek, M. W. (2017). Using the flipped classroom to enhance EFL learning. Computer Assisted Language Learning, 30(1-2), 1-21. https://doi.org/10.1080/09588221.2015.1111910

Chugh, R., \& Ruhi, U. (2018). Social media in higher education: A literatura review of Facebook. Education and Information Technologies, 23, 605-616. https://doi.org/10.1007/s10639-017-9621-2

Council of Europe (2001). Common European Framework of Reference for Languages: Learning, Teaching, Assessment (CEFR). Cambridge University Press.

Cózar-Gutiérrez, R., \& Sáez-López, J. M. (2016). Game-based learning and gamification in initial teacher training in the social sciences: an experiment with MinecraftEdu. International Journal of Educational Technology in Higher Education, 13(2), 1-11. https://doi.org/10.1186/s41239-016-0003-4

Daher, W. M. (2014). Students' adoption of social networks as environments for learning and teaching: The Case of the Facebook. International Journal of Emerging Technologies in Learning, 9(8), 16-24. https://doi.org/10.3991/ijet.v9i8.3722

David, N., \& Akcaoglu, M. (2014). Internet and Higher Education "I see smart people!": Using Facebook to supplement cognitive and affective learning in the university mass lecture. The Internet and Higher Education, 23, 1-8. https://doi.org/10.1016/j.iheduc.2014.05.003

Dweikat, K. (2016) Impact of using Facebook on improving English communication skills - The case of implementing the English language course as a model at Al-Quds Open University. An - Najah Univ. J. $\begin{array}{lll}\text { Res. } & \text { (Humanities), }\end{array}$

2287-2318. https://journals.najah.edu/media/journals/full_texts/7_PuvJtzW.pdf 
Ellison, N. B., Steinfield, C., \& Lampe, C. (2011). Connection strategies: Social capital implications of Facebookenabled communication practices. New Media \& Society, 13(6), 873-892. https://doi.org/10.1177/1461444810385389

Fernández-Ferrer, M., \& Cano, E. (2019). Experiencias de retroacción para mejorar la evaluación continuada: El uso de Twitter como tecnología emergente. Educar, 55(2), 437-455. https://doi.org/10.5565/rev/educar.872

Gallardo-López, J.A., \& López-Noguero, F. (2020). Twitter como recurso metodológico en Educación Superior: Una experiencia educativa con estudiantes de Trabajo Social. Alteridad. Revista de Educación, 15(2), 174-189. https://doi.org/10.17163/alt.v15n2.2020.03

Gettman, H. J., \& Cortijo, V. (2015). "Leave me and my Facebook alone!" Understanding college students' relationship with Facebook and its use for academic purposes. International Journal for the Scholarship of Teaching and Learning, 9(1), 1-16. https://doi.org/10.1177/0735633117745161

Hewings, M. (2013). Advanced grammar in use. Cambridge University Press.

Hutchens, J. S., \& Hayes, T. (2014). Examining Facebook usage as misbehavior on perceived teacher credibility. Education and Information Technologies, 19(1). 5-20. http://www. https://eric.ed.gov/?id=EJ1053085

Hung, H. T. (2015). Flipping the classroom for English language learners to foster active learning. Computer Assisted Language Learning, 28(1), 81-96. https://doi.org/10.1080/09588221.2014.967701

Ibrahim, M. (2013). The effect of using Facebook on improving students' writing skills in English. (Unpublished MA Thesis). An- Najah National University, Nablus, Palestine.

Junco, R. (2012). The relationship between frequency of Facebook use, participation in Facebook activities, and student engagement. Computers \& Education, 58, 162-171. https://doi.org/10.1016/j.compedu.2011.08.004

Kabilan, M. K., Ahmad, N., \& Abidin, M. J. Z. (2010). Facebook: An online environment for learning of English in institutions of higher education? Internet and Higher Education, 13(4), 179-187. https://doi.org/10.1016/j.iheduc.2010.07.003

Kukulska-Hulme, A., \& Viberg, O. (2018). Mobile collaborative language learning: state of the art. British Journal of Educational Technology, 49(2), 207-218. https://doi.org/10.1111/bjet.12580

Law, K. M., Geng, S., \& Li, T. (2019). Student enrollment, motivation and learning performance in a blended learning environment: The mediating effects of social, teaching, and cognitive presence. Computers \& Education, 136, 1-12. https://doi.org/10.1016/j.compedu.2019.02.021

Li, K.-H., Lou, S.-J. Tseng, K. H., \& Huang, H. C. (2013). A preliminary study on the Facebook-based learning platform integrated with blended learning model and flip Learning for online classroom learning. Lecture Notes in Computer Science, 8167, 172-183.

Lin, C. H., Warschauer, M., \& Blake, R. (2016). Language learning through social networks: Perceptions and reality. Language Learning \& Technology, 20(1), 124-147. https://doi.org/10125/44449

Lomicka, L., \& Lord, G. (2016). Social networking and language learning. In F. Farr, \& L. Murray (Eds.), The Routledge handbook of language learning and technology (pp. 255-268). Routledge.

Majid, A., Stapa, S., \& Keong, Y. (2015). Blended scaffolding strategies through Facebook for learning and improving the writing process and writing performance. E-BANGI, 10(1), 31-39. https://ejournal.ukm.my/ebangi/article/view/10990

Manca, S., \& Ranieri, M. (2016). Facebook and the others. Potentials and obstacles of social media for teaching in higher education. Computers and Education, 95, 216-230. https://doi.org/10.1016/j.compedu.2016.01.012 
Mariappan, L., Abu, A. G. B., \& Omar, A. B. (2017). Facebooking for a more lively interaction in literature classrooms. Creative Education, 8, 749-763. https://doi.org/10.4236/ce.2017.85056

Marín-Díaz, V., \& Cabero-Almenara, J. (2019). Las redes sociales en educación: Desde la innovación a la investigación educativa. RIED. Revista Iberoamericana de Educación a Distancia, 22(2), 25-33. https://doi.org/10.5944/ried.22.2.24248

Martín del Campo Fernández-Paniagua, A. (2020). Las Redes Sociales más utilizadas: cifras y estadísticas [The most used social networks: figures and statistics]. https://www.iebschool.com/blog/medios-socialesmas-utilizadas-redes-sociales/

Martín-Monje, E., Castrillo, M. D., \& Mañana-Rodríguez, J. (2018). Understanding online interaction in language MOOCs through learning analytics. Computer Assisted Language Learning, 31(3), 251-272. https://doi.org/10.1080/09588221.2017.1378237

Mazer, J. P., Murphy, R. E., \& Simonds, C. J. (2007). I'Il see you on Facebook: The effects of computermediated teacher self-disclosure on student motivation, affective learning, and classroom climate. Communication Education, 56(1), 1-17. https://doi.org/10.1080/03634520601009710

Melor, Y., \& Salehi, H. (2012). The effectiveness of Facebook groups on teaching and improving writing: Students' perceptions. International Journal of Education and Information Technologies, 6(1), 87-96. http://research.iaun.ac.ir/pd/hadisalehi/pdfs/PaperM_7787.pdf

Miller, R.E. (2020). College students and inappropriate social media posting: Is it a question of personality or the influence of friends? Personality and Individual Differences, 158, 109857. https://doi.org/10.1016/j.paid.2020.109857

Newberry, C. (2020). 33 estadísticas de Facebook que todo mercadólogo debe conocer en 2020 [33 Facebook statistics every marketer should know in 2020]. https://blog.hootsuite.com/es/estadisticas-defacebook/

Pourhossein, A. (2017). A review of the literature on the integration of technology into the learning and teaching of English language skills. International Journal of English Linguistics, 7(5), 95-106. https://doi.org/10.5539/ijel.v7n5p95

Ru-Chu, S. (2011). Can Web 2.0 technology assist college students in learning English writing? Integrating "Facebook" and peer assessment with blended learning. Australasian Journal of Educational Technology, 27(5), 829-845. https://doi.org/10.14742/ajet.934

Ruiz, M., \& Fachinetti, V. (2018). Los estudiantes, los sentidos de la formación universitaria. Twitter como recurso metodológico en Educación Superior: Una experiencia educativa con estudiantes de Trabajo Social [Students, the senses of university education. Twitter as a methodological resource in Higher Education: An educational experience with Social Work students]. InterCambios. Dilemas y transiciones $\begin{array}{lllll}\text { de la } & \text { Educacion }\end{array}$ https://ojs.intercambios.cse.udelar.edu.uy/index.php/ic/article/view/148

Rwodzi, C., De Jager, L., \& Mpofu, N. (2020). The innovative use of social media for teaching English as a second language. The Journal for Transdisciplinary Research in Southern Africa 16(1), 702-708. https://doi.org/10.4102/td.v16i1.702

Seaman, J., \& Tinti-Kane, H. (2013). Social media for teaching and learning. Pearson Learning Systems.

Shih, R.C. (2011). Can Web 2.0 technology assist college students in learning English writing? Integrating Facebook and peer assessment with blended learning. Australasian Journal of Educational Technology, 27(5), 829-845. https://doi.org/10.14742/ajet.934 
Shraim, K. (2014). Pedagogical innovation within Facebook: A case study in tertiary education in Palestine. International Journal of Emerging Technologies in Learning (iJET), 9(8), 25-44. https://onlinejournals.org/index.php/i-jet/article/view/3805

Solmaz, O. (2018). A critical review of research on social networking sites in language teaching and learning. Contemporary Educational Technology, 9(3), 315-330. https://doi.org/10.30935/cet.444120

Torgeson, K. (2006). Facebook stirs uproar over online privacy. The Johns-Hopkins Newsletter 9/21. http://media.www.jhunewsletter.com

Vahdat, S., Gooniband Shooshtari, Z. \& Mazareian, F. (2020). The impact of the Telegram on learning of collocational knowledge among Iranian EFL high school students. Applied Linguisics Research Journal, 2(3), 37-51. https://doi.org/10.14744/alrj.2020.18189

Vikneswaran, T., \& Krish, P. (2014). Utilising social networking sites to improve writing: a case study with Chinese students in Malaysia. Technology, Pedagogy and Education, 25(3), 287-300. https://doi.org/10.1080/1475939X.2015.1030441

Vural, O. F. (2015). Positive and negative aspects of using social networks in higher education: A focus group study. Educational Research and Reviews, 10(8), 1147-1166. https://doi.org/10.5897/err2015.21.3.44

We are social \& Hootsuite (2020). Digital 2020: Global Digital Overview. https://datareportal.com/reports/digital-2020-global-digital-overview

Correspondence: María Martínez Lirola, University of Alicante, Spain and University of South Africa (UNISA), South Africa. E-mail: maria.lirola@ua.es 


\section{APPENDIX 1}

\section{Questionnaire on the Use of Facebook and Social Competences}

1. Have you used Facebook with educational purposes in any other subject during the degree?

Yes No

2. After participating in the preparation of the oral presentation and discussion on Facebook based on a social topic, are you more aware of social situations?

Yes No

Why?

3.Which of the following social competences have you developed more with the preparation and participation in oral presentations and the discussions through Facebook?

\section{Communication}

Cooperation

Leadership

Conflict solving

4. Has the use of the Facebook group contributed positively to improving your language knowledge? ( 1 is the lowest and 5 is the highest)

5. Has the use of the Facebook group contributed positively to improving your motivation to communicate using English? ( 1 is the lowest and 5 is the highest)

6. Has the use of the Facebook group contributed positively to improving your knowledge about social topics? ( 1 is the lowest and 5 is the highest)

7. Has the participation in the Facebook group contributed to improving your writing fluency? ( 1 is the lowest and 5 is the highest)

8. Could Facebook be considered as an effective supplementary learning platform to practice writing in English? ( 1 is the lowest and 5 is the highest)

9. Could Facebook be considered as an effective supplementary learning platform to read in English? (1 is the lowest and 5 is the highest)

10. Could Facebook be considered as an effective supplementary learning platform to overcome language mistakes? ( 1 is the lowest and 5 is the highest) 